
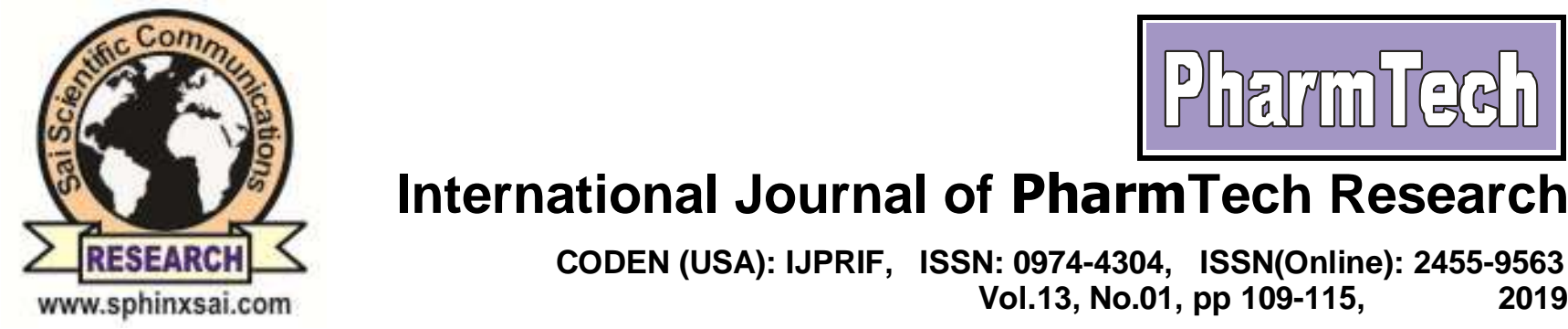

International Journal of PharmTech Research

CODEN (USA): IJPRIF, ISSN: 0974-4304, ISSN(Online): 2455-9563

Vol.13, No.01, pp 109-115,

2019

\title{
Green Stabilization of Clay Soil Using Cement Kiln Dust
}

\author{
P. Kodanda Rama Rao', C.Rajakumar ${ }^{2}$ \\ ${ }^{1}$ Professor \& Head, Department of Civil Engineering, \\ Gudlavalleru Engineering College, Gudlavalleru, Andhrapradesh, India \\ ${ }^{2}$ Associate Professor, Department of Civil Engineering, \\ Gudlavalleru Engineering College, Gudlavalleru, Andhrapradesh, India
}

\begin{abstract}
This research work is aimed to evaluate the suitability of cement kiln dust for stabilization of expansive clay soil in Coimbatore. The laboratory work involved index properties to classify the soil sample. The preliminary investigation of the soil shows that it belongs to $\mathrm{CH}$ class of soil in the BIS soil classification system. Soils under this class are generally of poor engineering use. Atterberg limits, free swell, free swell index, compaction, UCS and CBR tests were used to evaluate properties of stabilized soil. The soil was stabilized with cement kiln dust in stepped concentration of 5\%,10\%,15\%,20\%, 25\% and 30\% by dry weight of the soil. Analysis of the results shows that high improvement on the geotechnical properties of cement kiln dust stabilized soil. Cement kiln dust reduces plasticity index, swelling and MDD with an increase in OMC, UCS and CBR with all higher cement kiln dust contents. From this study it was found out that cement kiln dust stabilized soil meet the minimum requirement of IRC pavement specification for use as a sub-grade material in road construction. Key words : Expansive subgrade, Cement Kiln Dust (CKD), Atterberg limits, Compaction Tests, UCS, CBR.
\end{abstract}

\section{Introduction}

The black clay soil of this region has contributed to the Coimbatore's (Tamil Nadu, India) flourishing agriculture industry and it is in fact, the reason for the successful growth of cotton and served as a foundation for the establishment of its famous textile industry (Ahmad rifa'I 2009, Rahman et al 2011, Sharma 2011, Hesham and Ismaiel 2013, Vivek Singh and Rajesh Jain 2015,BIS 2720) .

Structures which are built over the black cotton soil are prone to fail or damages due to low shear strength, swell and shrinkage are characteristics features. Such soils are extensively found in and around Coimbatore for a considerable depth. This has resulted in the settlement of building, failure of pavement, bridges etc. On wetting, the black cotton soil becomes soft and exhibit very low shear strength and on drying the clay becomes hard and achieves very high shear strength. These alternate changes should be controlled and the soil should be limited to certain shear strength. The soil stabilization along with soil reinforcement is taken 
into consideration for the study of the behaviour of black cotton/expansive soil in Coimbatore. Recent trend in research works in the field of geotechnical engineering and construction materials focuses more on the search for cheap and locally available materials such as industrial wastes as stabilizing agents. These wastes can be treated as replacement for traditional stabilizers. Industrial waste is increasingly becoming a focus for researchers because of the enhanced pozzolanic capabilities of such wastes when oxidized by burning. Thus, this study aims at evaluating the possibility of utilizing industrial wastes such as cement kiln dust in the stabilization of black cotton soil in Coimbatore (Ahmad rifa'I 2009, Rahman et al 2011, Sharma 2011, Hesham and Ismaiel 2013, Vivek Singh and Rajesh Jain 2015, BIS 2720).

\section{Material and Methods}

\section{Methodology}

The present study is mainly focused on laboratory and experimental investigations for soil subgrade strength improvement. Experimental investigation, methodology has been adopted for assessing the effect of cement kiln dust stabilization on selected subgrade soil. Laboratory experimentations necessary for the present study have been carried out as per the guidelines and procedures specified by Indian standards as and when appropriate. IRC recommendations have been taken into considerations for the design of pavement configurations based on compacted subgrade with cement kiln dust (Ahmad rifa'I 2009, Rahman et al 2011, Sharma 2011, Hesham and Ismaiel 2013, Vivek Singh and Rajesh Jain 2015, BIS 2720)

\section{Materials}

\section{Collection of Clay}

Clay for this research work is collected from Ondipudur, Coimbatore, Tamilnadu state, India. The locations are $10.9983^{\circ} \mathrm{N}, 77.0536^{\circ} \mathrm{E}$. The soil sample was present at depth of 5 feet from ground level (BIS 2720).

\section{Cement Kiln Dust}

Industrial waste such as Cement kiln dust (Figure 1) was collected from ACC Cement Industry Madukkarai, Coimbatore.

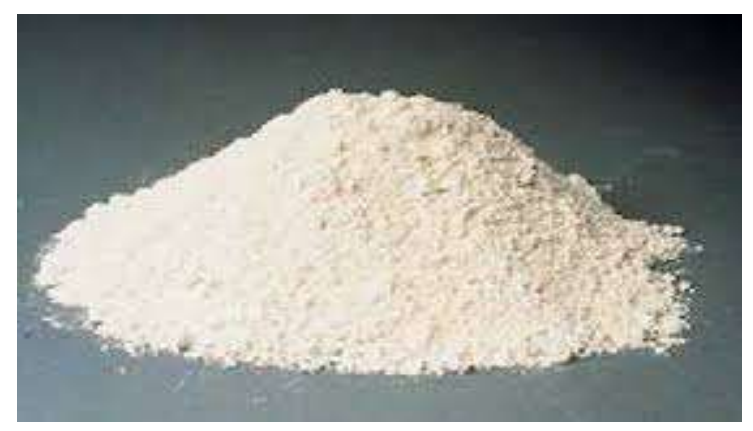

Fig.1 Cement Kiln Dust

\section{Mineral Composition of Cement Kiln Dust}

Mineral Composition of Cement Kiln Dust were obtained from PSG College of Technology, Coimbatore by conducting EDAX/SEM tests (Figure.2) and recorded in table.1(Ahmad rifa'I 2009, Rahman et al 2011, Sharma 2011, Hesham and Ismaiel 2013, Vivek Singh and Rajesh Jain 2015,BIS 2720). 


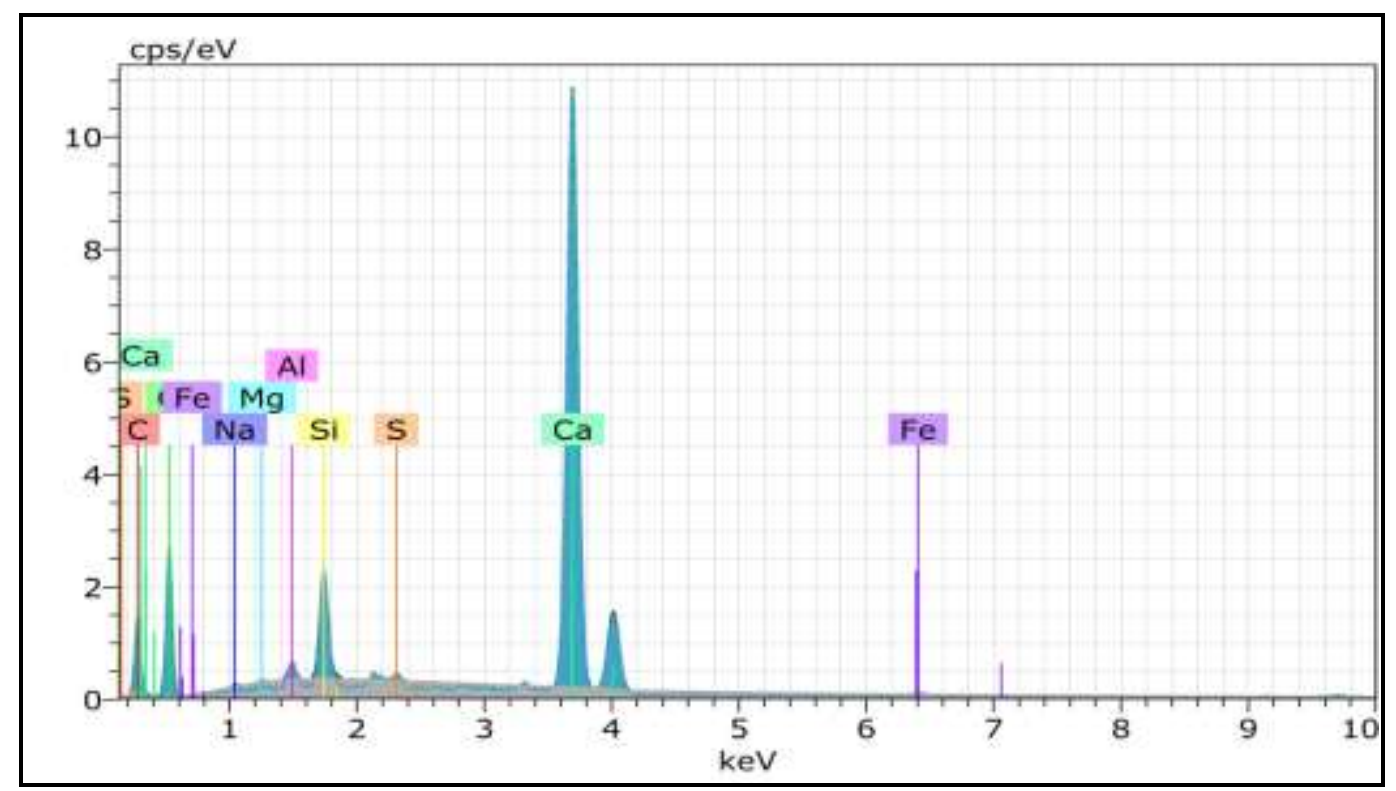

Figure.2 EDAX test Image

Table.1 Mineral Composition of CKD

\begin{tabular}{|l|l|}
\hline Mineral Composition & $\begin{array}{l}\text { Cement } \\
\text { Kiln Dust (\%) }\end{array}$ \\
\hline Silica $\left(\mathrm{SiO}_{2}\right)$ & 50.52 \\
\hline Alumina $\left(\mathrm{Al}_{2} \mathrm{O}_{3}\right)$ & 21.41 \\
\hline Calcium Oxide $(\mathrm{CaO})$ & 2.32 \\
\hline $\begin{array}{l}\text { Magnesium Oxide } \\
(\mathrm{MgO})\end{array}$ & 1.58 \\
\hline Potassium Oxide $\left(\mathrm{K}_{2} \mathrm{O}\right)$ & 1.03 \\
\hline Loss of Ignition $(\mathrm{LOI})$ & 15.96 \\
\hline Phosphorous $\left(\mathrm{P}_{2} \mathrm{O}_{5}\right)$ & 0.48 \\
\hline
\end{tabular}

\section{Laboratory Investigation}

Laboratory tests are conducted in the Geotechnical laboratory with the collected soil sample to classify the clay, to evaluate its physical and engineering properties and study the compaction characteristics. Standard Proctor Compaction Test ,Unconfined Compressive Strength Test, CBR (unsoaked and soaked) tests are conducted on samples with 5\%,10\%, 15\%, 20\%, 25\% and 30\% addition of cement kiln dust. The Standard Proctor Compaction tests are conducted on the sample to evaluate the Optimum Moisture Content and Maximum dry density of soils. Unconfined Compressive Strength tests are conducted to evaluate the unconfined compressive strength and cohesion. The CBR value for the virgin soil is obtained. Results are analyzed and conclusions are made based on the results (Ahmad rifa'I 2009, Rahman et al 2011, Sharma 2011, Hesham and Ismaiel 2013, Vivek Singh and Rajesh Jain 2015, BIS 2720).

The results are reported in table 2 . 
Table.2 Properties of clay (BIS 2720)

\begin{tabular}{|c|c|c|}
\hline S.no & Properties & Result \\
\hline 1 & Natural Moisture Content & $13.42 \%$ \\
\hline 2 & Specific Gravity & 2.60 \\
\hline 3 & $\begin{array}{l}\text { Sieve Analysis \% of Gravel } \\
\% \text { of sand } \\
\% \text { of Silt } \\
\% \text { of Clay }\end{array}$ & $\begin{array}{l}3.5 \% \\
22.35 \% \\
25.5 \% \\
51.4 \% \\
\end{array}$ \\
\hline 4 & Differential Free Swell Index & $55 \%$ \\
\hline \multirow{10}{*}{5} & Liquid Limit $\left(\mathrm{W}_{\mathrm{L}}\right)$ & $55 \%$ \\
\hline & Plastic Limit $\left(\mathrm{W}_{\mathrm{P}}\right)$ & $16 \%$ \\
\hline & Shrinkage Limit $\left(\mathrm{W}_{\mathrm{S}}\right)$ & $14 \%$ \\
\hline & Flow Index $\left(\mathrm{I}_{\mathrm{f}}\right)$ & 23 \\
\hline & Plasticity Index $\left(\mathrm{I}_{\mathrm{P}}\right)$ & $39 \%$ \\
\hline & Toughness Index $\left(I_{t}\right)$ & 1.11 \\
\hline & Liquidity Index( $\left.\mathrm{I}_{\mathrm{L}}\right)$ & $-26 \%$ \\
\hline & Consistency Index $\quad\left(\mathrm{I}_{\mathrm{C}}\right)$ & $112.7 \%$ \\
\hline & Soil Classification & $\mathrm{CH}$ \\
\hline & Activity (A) & 0.56 \\
\hline \multirow{2}{*}{6} & Optimum Moisture Content & $16 \%$ \\
\hline & Maximum Dry Density & $1.65 \mathrm{~g} / \mathrm{cc}$ \\
\hline \multirow{2}{*}{7} & Unconfined Compressive Strength $\left(\mathrm{q}_{\mathrm{u}}\right)$ & $90.8 \mathrm{kN} / \mathrm{m}^{2}$ \\
\hline & Cohesion $\left(\mathrm{C}_{\mathrm{u}}\right)$ & $45.40 \mathrm{~N} / \mathrm{m}^{2}$ \\
\hline 8 & $\begin{array}{l}\text { CBR unsoaked } \\
\text { CBR soaked }\end{array}$ & $\begin{array}{l}11.58 \% \\
2.88 \%\end{array}$ \\
\hline
\end{tabular}

\section{Experimental Study}

Experimental study elaborates on various engineering properties of soil such as natural moisture content, specific gravity, liquid limit, plastic limit, shrinkage limit, particle size distribution, Optimum Moisture Content, Maximum Dry Density, Unconfined Compressive Strength(UCS), California Bearing Ratio (CBR), free swell Index etc., (Ahmad rifa'I 2009, Rahman et al 2011, Sharma 2011, Hesham and Ismaiel 2013, Vivek Singh and Rajesh Jain 2015,BIS 2720).

\section{Compaction Test}

Standard Proctor Compaction tests are conducted on soil samples with addition of cement kiln dust in proportions of 5\%, 10\%, 15\%, 20\%, 25\% and 30\% of the weight of soil sample. The variation of Maximum Dry Density and Optimum Moisture Content is recorded (Figure 3) (Ahmad rifa'I 2009, Rahman et al 2011, Sharma 2011, Hesham and Ismaiel 2013, Vivek Singh and Rajesh Jain 2015,BIS 2720).

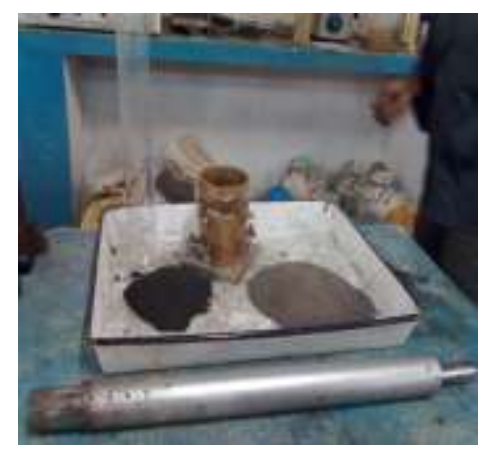

Figure 3: Compaction test 


\section{Unconfined Compressive Strength Test}

Unconfined Compressive Strength tests are conducted on soil samples with addition of Cement kiln dust in proportions of 5\%,10\%, 15\%, 20\%, 25\% and 30\% of the weight of soil samples (figure 4 and 5) (BIS 2720).
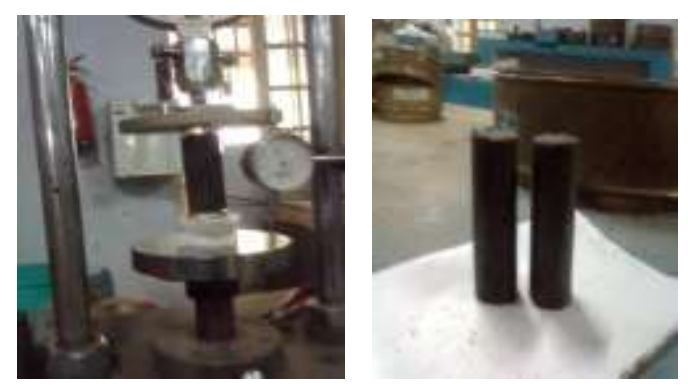

Figure.4 UCC test apparatus with specimen

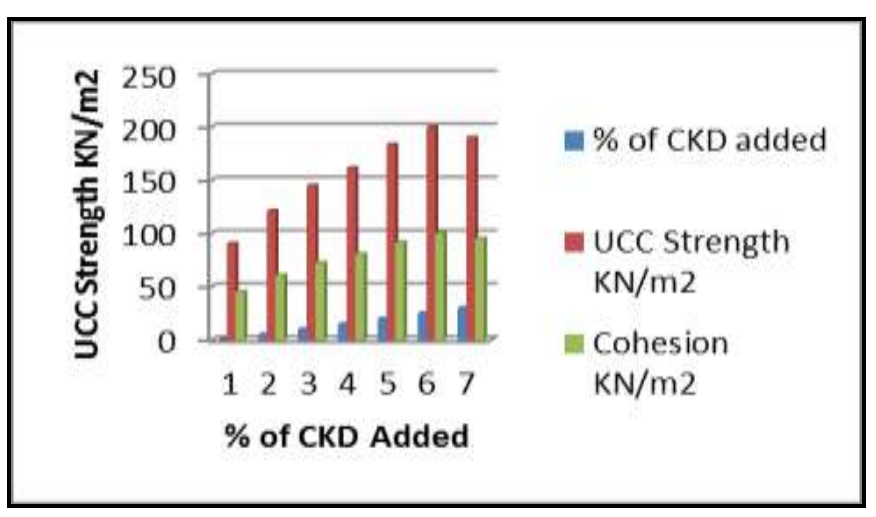

Figure.5 Variation of UCC Strength with the addition of CKD

\section{California Bearing Ratio Test}

California bearing ratio tests are conducted in order to determine the California bearing ratio value for soil with optimum percent of cement kiln dust (Figure7). The samples are compacted at optimum moisture content for both unsoaked and soaked test (Figure 6 and 7).
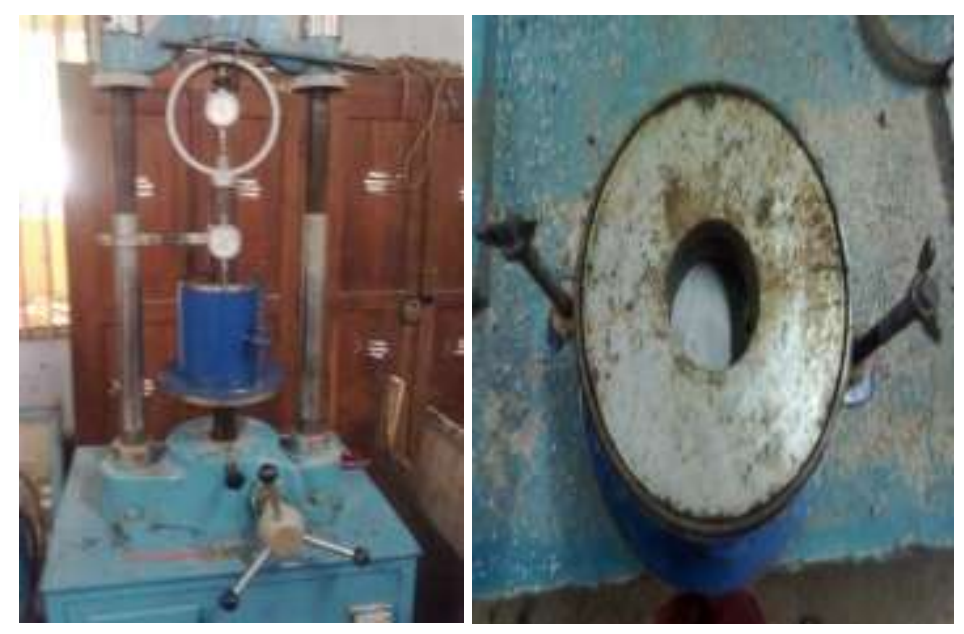

Figure.6 CBR Test with compacted sample 


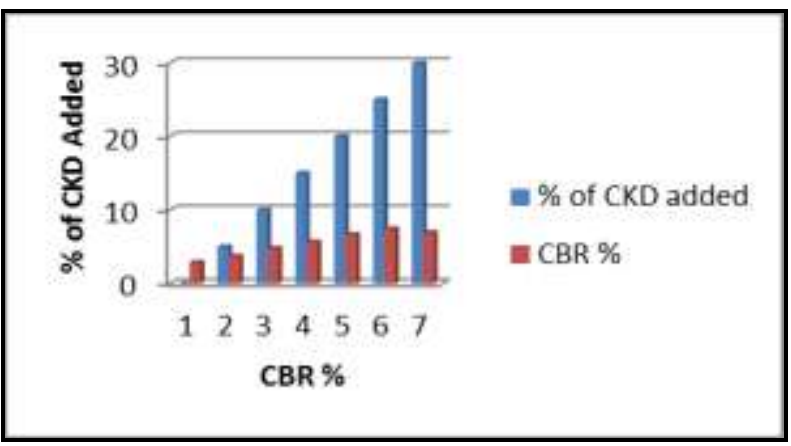

Figure. 7 Variation of Soaked CBR with addition of CKD

\section{Conclusions}

Based on the experimental investigations on stabilization of clay, the following conclusions are drawn.

1. The initial laboratory investigations showed that collected clay soil sample is solid, stiff and has high compressibility.

2. The optimum percentage replacement of fly ash is found to be $25 \%$ with double layer of geogrid.

3. The results improved at $25 \%$ replacement are as follows - The liquid limit, plasticity index decreases and maximum dry density shows a significant change.

4. The optimum moisture content increases with increase in Cement Kiln dust replacement.

5. The unconfined compressive strength of untreated soil is $90.8 \mathrm{KN} / \mathrm{m} 2$. The addition of CKD has increased the UCC strength to $200.48 \mathrm{KN} / \mathrm{m}^{2}$ at $25 \% \mathrm{CKD}$

6. The blend suggested from this investigation is clay with $25 \%$ replacement by CKD, would be an economical approach.

7. Furthermore if the soil reinforcement is provided, there will be more perfection in properties of expansive soil.

\section{References}

1. Vivek Singh, Rajesh Jain, 2015, Effect of Cement kiln dust on Index properties of Black cotton soil, International Journal of Engineering \& Science Research, Vol-5, Issue-4,142-146.

2. Rahman, Rehman,O. S. B. Al-Amoudi,2011, Literature review on cement kiln dust usage in soil and waste stabilization and experimental investigation, IJRRAS, Vol 7,Issue1,77-87.

3. Hesham A. H. Ismaiel ,2013,Cement Kiln Dust Chemical Stabilization of Expansive Soil Exposed at El-Kawther Quarter, Sohag Region, Egypt, International Journal of Geosciences, 4, 1416-1424.

4. Ambarish Ghosh, Utpal Dey, 2009, "Bearing ratio of reinforced fly ash overlying soft soil and deformation modulus of fly ash", Geo textiles and Geo membranes 27 (2009),313-320

5. Ahmad rifa'i, Noriyuki yasufuku, Kiyoshi omine and Kazuyoshi tsuji,2009, "Experimental study of coal ash utilization for road application on soft soil", Geotechnical Society of Singapore (GeoSS).2009,356-362

6. Pandian NS, 2004, "Fly ash characterization with reference to geotechnical applications", Journal of IISC, 84,189-216

7. Phani Kumar SR, Sharma RS (2004), "Effect of fly ash on engineering properties of expansive soils", Journal of Geotechnical and Geo environmental Engineering, 130(7):764-767

8. Sharma NK, 2011, "Stabilization of clayey soil with fly ash and lime: A micro level investigation", Geotechnical and Geological Engineering.

9. $\quad$ IS: 2720 (Part 2) - 1973 (Determination of Water Content)

10. IS: 2720 (Part 3/Section 1) - 1980 [Part 3 - Determination Of Specific Gravity (Section -1 Fine Grained Soils)]

11. IS: 2720 (Part 4) - 1985 (Grain Size Analysis)

12. IS: 2720 (Part 40) -1977 (Determination of Free Swell Index of Soils)

13. IS: 2720 (Part 5) -1985 (Determination of Liquid and Plastic Limit) 
14. IS: 1498-1970 (Classification and Identification of Soils for general engineering purposes)

15. IS: 2720 (Part 7) -1980 (Determination Of Water Content-Dry Density Relation Using Light Compaction)

16. IS: 2720 (Part 10) -1991 (Determination of Unconfined Compressive Strength)

17. IS: 2720 (Part 16) -1987 (Laboratory Determination of CBR)

$* * * * *$ 